\title{
Ground Water Quality Assessment of Daur Taluka, Shaheed Benazir Abad
}

\author{
Nadeem-ul-Karim Bhatti \\ Department of Civi Engineering \\ Quaid-e-Awam University of Engineering, Science \& \\ Technology \\ Larkana, Pakistan \\ knadeem b@quest.edu.pk
}

\author{
Salem Raza Samo \\ Department of Energy \& Environment \\ Quaid-e-Awam University of Engineering, Science \& \\ Technology \\ Nawabshah, Pakistan \\ sfaizsamo@yahoo.com
}

\author{
Abdullah Saand \\ Department of Civil Engineering \\ Quaid-e-Awam University of \\ Engineering, Science \& Technology \\ Nawabshah, Pakistan \\ abdullah@quest.edu.pk
}

\author{
Manthar Ali Keerio \\ Department of Civil Engineering \\ Quaid-e-Awam University of \\ Engineering, Science \& Technology \\ Larkana, Pakistan \\ mantharali99@quest.edu.pk
}

\author{
Ahsan Ali Bhuriro \\ Department of Civil Engineering \\ Quaid-e-Awam University of \\ Engineering, Science \& Technology \\ Larkana, Pakistan \\ ahsanone@gmail.com
}

\begin{abstract}
The aim of this study was to assess the ground water quality of Daur Taluka of district Shaheed Benazir Abad for drinking purposes. Forty groundwater samples were collected from different locations and brought to Pakistan Council of Research in Water Resources (PCRWR) for analyzing various groundwater physical, chemical and biological parameters. The results of this study revealed that color, $\mathrm{pH}$, magnesium, alkalinity and nitrate of all samples were found within the permissible limits of World Health Organization (WHO). Analytical results revealed that the percentage of samples that were beyond WHO standards was $15 \%$ regarding taste, $42.5 \%$ regarding TDS, $20 \%$ regarding chlorine, $12.5 \%$ regarding sulfate 12.5 regarding sodium and $32.5 \%$ regarding hardness. Microbiological contamination was found positive in the $25 \%$ of samples. The findings of this study revealed that the most $(82.5 \%)$ of the samples of the study area belong to the category of hard to very hard water and their nature were alkaline.
\end{abstract}

Keywords-water quality parameters; arsenic; Taluka Daur; Shaheed Benazir Abad; WHO standards

\section{INTRODUCTION}

Water is one of the most important ecosystem and climate components. Water quantity and quality determine the biodiversity of an ecosystem. Water quantity and quality is not distributed evenly in the world [1,2]. Safe drinking water is not only a fundamental requirement of all living organisms but also an indispensable human right [3, 4]. Insufficient availability of fresh water coerces people to use ground water for meeting their needs. About $70 \%$ of Pakistan households use ground water for domestic purposes $[5,6]$. Water also becomes a vital source of increasing demand for agriculture and industry [7]. The quality of ground water in Sindh region is worsening due to overuse of fresh water layer. Sindh is an arid region, so ground water is recharged only during flooding time along the water channel sides $[8,9]$. About $78 \%$ of Sindh province has saline ground water whose salinity varies and at maximum is $9 \mathrm{dS} / \mathrm{m}[7,10]$. The groundwater is polluted due to various natural and anthropogenic factors. The disposal of untreated effluents from industries and household sewage, seepage of fertilizers and land degradation are the main sources of groundwater pollution [11-14]. The quality of ground water of Sindh urban and suburban areas is very poor and chemically and bacteriologically not fit for drinking purposes [15]. The consumption of contaminated water causes various diseases [16]. About 98\% of the households of Shaheed Benazir Abad are using ground water [17]. The aim of this study is to assess the ground water quality of four sites of Taluka Daur of Shaheed Benazir Abad for drinking purposes.

\section{Methodology}

Forty groundwater samples were collected from different locations of four union councils of Taluka Daur (Daur, Bandhi, Jam Sahib and Bucheri) of district Shaheed Benazir Abad. Ten water samples have been taken from each union council. Sterilized plastic bottles were used for collecting the samples which were washed with distilled water twice prior to sampling. The samples were collected by using standard methods suggested in $[18,19]$. The collected water samples were brought to Pakistan Council of Research in Water Resources (PCRWR) regional laboratory for analyzing regarding the following selected physical and chemical groundwater parameters (methods of analysis and concerned instruments employed for each water quality parameter are summarized in Table I). 


\section{A. Physical Water Parameters under Study}

These parameters of water are turbidity, electrical conductivity, $\mathrm{pH}$, taste and color.

\section{B. Chemical Water Parameters under Study}

These parameters were bicarbonate $(\mathrm{HCO} 3)$, chlorine $(\mathrm{Cl})$, sulfate $\left(\mathrm{SO}_{4}\right)$, hardness, calcium $(\mathrm{Ca})$, magnesium $(\mathrm{Mg})$, sodium $(\mathrm{Na})$, potassium $(\mathrm{K})$, alkalinity $\left(\mathrm{CaCo}_{3}\right)$, total dissolved solids (TDS) and nitrate $\left(\mathrm{NO}_{3}\right)$.

\section{Biological Water Aspects under Study}

Presence-absence test kit was used to evaluate the water samples for microbiological contamination. American Public Health Association's guidelines were followed for examining the water samples and calibrating the equipment and instruments [20].

TABLE I. WATER QUALITY PARAMETERS AND METHODS OF ANALYSIS

\begin{tabular}{|c|c|c|}
\hline S. No. & $\begin{array}{c}\text { Water Quality } \\
\text { Parameter }\end{array}$ & Method of analysis \\
\hline 1 & TDS & 2540C, Standard method (1992) \\
\hline 2 & $\begin{array}{c}\text { Conductivity } \\
(\mu \mathrm{S} / \mathrm{cm})\end{array}$ & $\begin{array}{c}\text { E.C. meter, Syber Scan CON 11 } \\
\text { Singapore }\end{array}$ \\
\hline 3 & PH & $\begin{array}{c}\text { Jenco Handheld pH meter, Model } \\
6230 \mathrm{~N}\end{array}$ \\
\hline 4 & Color $(\mathrm{TCU})$ & Sensory Test \\
\hline 5 & Taste & Sensory Test \\
\hline 6 & Bicarbonate $(\mathrm{mg} / \mathrm{l})$ & 2320, Standard method (1992) \\
\hline 7 & Chloride $(\mathrm{mg} / \mathrm{l})$ & Titration Standard method (1992) \\
\hline 8 & Sulfate & $\begin{array}{c}\text { Spectrophotometer Optizen 2120UV } \\
\text { plus Korea }\end{array}$ \\
\hline 9 & Hardness (mg/l) & $\begin{array}{c}\text { EDTA Titration Standard method } \\
(1992)\end{array}$ \\
\hline 10 & Calcium $(\mathrm{mg} / \mathrm{l})$ & $3500-$ Ca-D, Standard method (1992) \\
\hline 11 & Magnesium $(\mathrm{mg} / \mathrm{l})$ & $234-\mathrm{C}$, Standard method (1992) \\
\hline 12 & Sodium $(\mathrm{mg} / \mathrm{l})$ & Flame photometer Italy \\
\hline 13 & Potassium & Flame photometer \\
\hline 14 & Alkalinity & 2320, Standard method (1992) \\
\hline 15 & Turbidity & $\begin{array}{c}\text { Turbidity meter Lovibond PC check kit } \\
\text { Germany }\end{array}$ \\
\hline 16 & Nitrate & Colorimeter, Hach- DR2800, USA \\
\hline 17 & B.C & Presence /absence test kit \\
\hline
\end{tabular}

Statistical methods were used to find the minimum, maximum, mean and range of all water quality parameters. The results were compared and evaluated with the help of WHO guidelines for physical and chemical water characteristics.

\section{RESULTS AND DISCUSSION}

\section{A. Color}

Pure water is usually considered as colorless but it actually possesses a slightly blue hue. The sources of color in ground water are natural and anthropogenic. The particular geological formation or some metallic species of the region or seepage of effluent impact the groundwater color. WHO set the $15 \mathrm{TCU}$ limit for the color of drinking water. All samples were aesthetically good and clear.

\section{B. Taste and Odor}

The taste and odor of 34 samples are non-objectionable. Only 6 samples possessed objectionable taste.

\section{TDS}

TDS level is a good indicator of taste. Less than $300 \mathrm{mg} / \mathrm{l}$ is excellent, in the range between 300 and $600 \mathrm{mg} / \mathrm{l}$ is good, from 600 to $900 \mathrm{mg} / \mathrm{l}$ is fair, between 900 and $1200 \mathrm{mg} / 1$ is poor and greater than $1200 \mathrm{mg} / \mathrm{l}$ is not acceptable [19]. The upper limit of TDS of drinking water should be $1000 \mathrm{mg} / \mathrm{l}$ according to WHO standards. Figure 1 shows the results of TDS for all samples. Results indicate that the TDS of $23(57.5 \%)$ samples is within the permissible limits. The range of TDS of the entire samples was $100-3290 \mathrm{mg} / \mathrm{l}$ and the average value was $1273 \mathrm{mg} / \mathrm{l}$. Further analysis showed that 3 samples were excellent, 7 were good, 5 were fair and 7 were poor in taste while the remaining samples were not acceptable.

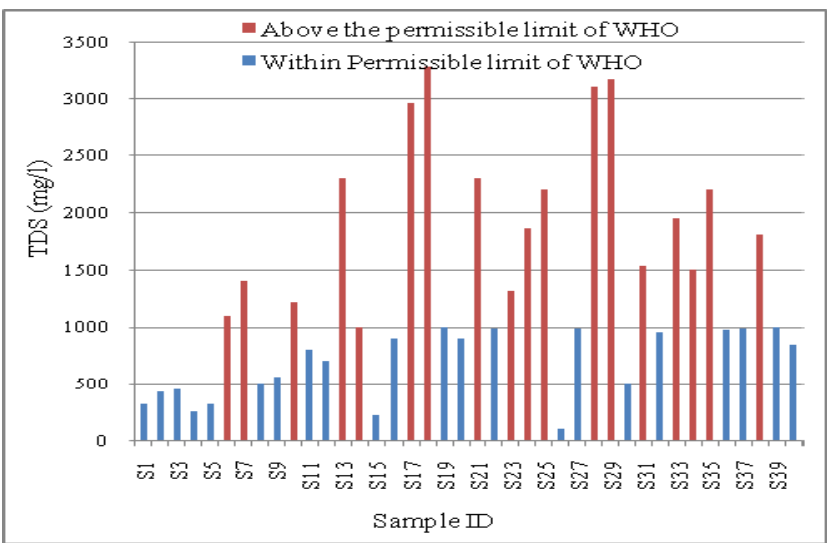

Fig. 1. Comparison of results of TDS of the entire samples

\section{Electrical Conductivity (EC)}

No guide line value has been given by WHO and USEPA for EC. The range of EC of all 40 samples was found as 389$5140 \mu \mathrm{S} / \mathrm{cm}$ and the average value was $2103.7 \mu \mathrm{S} / \mathrm{cm}$.

\section{E. $p H$}

$\mathrm{pH}$ is a very important water quality parameter which describes its acidic or alkaline nature. Drinking water $\mathrm{pH}$ should range from 6.5 to 8.5 according to WHO standards. Results show that the $\mathrm{pH}$ of all samples is within permissible limits. The range of $\mathrm{pH}$ of all samples was 6.7-7.6 and the average value was 7.2. The $\mathrm{pH}$ values of 8 samples were below 7 and the values of the remaining samples were greater than 7 . This shows that the nature of most of the ground water in the study area is alkaline.

\section{F. Bicarbonate}

Bicarbonate is the main anion in ground water. It derives from $\mathrm{CO}_{2}$ released as a consequence of organic decay in the soil. No guide line value of bicarbonate $\left(\mathrm{HCO}_{3}\right)$ has been given by WHO. The range of $\mathrm{HCO}_{3}$ of all tested 40 samples was 60 $680 \mathrm{mg} / \mathrm{l}$ and the average value was $295.25 \mathrm{mg} / \mathrm{l}$. 


\section{G. Chlorine (Cl)}

There are the various $\mathrm{Cl}$ sources in groundwater. These sources are leaching from mineral rock or soil, seepage of domestic and industrial effluent, sea water intrusion etc. [21]. Ground water shows higher $\mathrm{Cl}$ concentration compared to surface water. $\mathrm{Cl}$ is essential for metabolic activity and other physiological processes of human body but excess concentration of $\mathrm{Cl}$ is also detrimental [5]. The highest desirable limit of chloride in drinking water is accredited as $250 \mathrm{mg} / \mathrm{l}$ by WHO. Results of $\mathrm{Cl}$ concentration for all study area samples are shown in Figure 2

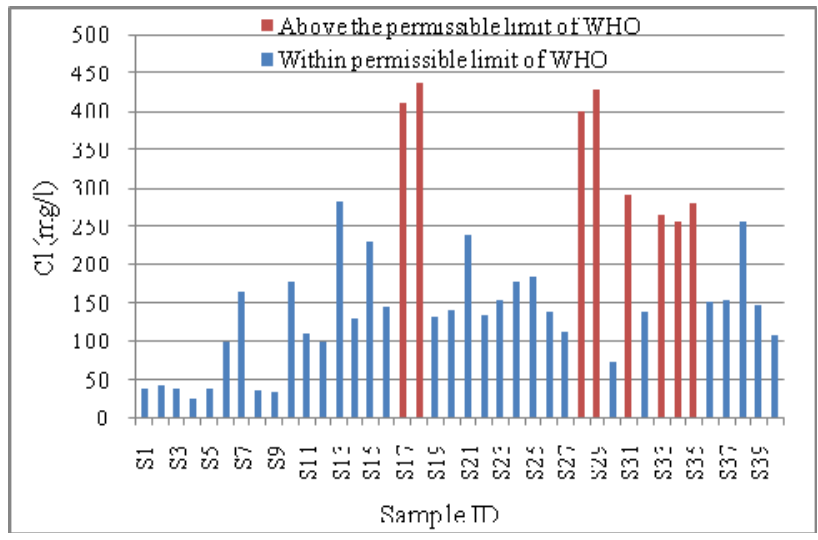

Fig. 2. Comparison of results of $\mathrm{Cl}$ of all samples

Figure 2 indicates that the $\mathrm{Cl}$ concentration of 32 samples is within the limit given by WHO while $20 \%$ of the samples are exceeding it. Water containing $\mathrm{Cl}$ in concentration greater than $250 \mathrm{mg} / \mathrm{l}$ has salty taste. The range of $\mathrm{Cl}$ of all the samples was $25-437 \mathrm{mg} / \mathrm{l}$ and the average value was $172.47 \mathrm{mg} / 1$.

\section{H. Sulfate $\left(\mathrm{SO}_{4}\right)$}

Laxative effect is associated with water ingestion containing elevated sulfate level [22]. The highest desirable limit of sulfate is acknowledged as $250 \mathrm{mg} / 1$ in drinking water by WHO. Figure 3 shows the results of Sulfate $\left(\mathrm{SO}_{4}\right)$ concentration in the study area samples.

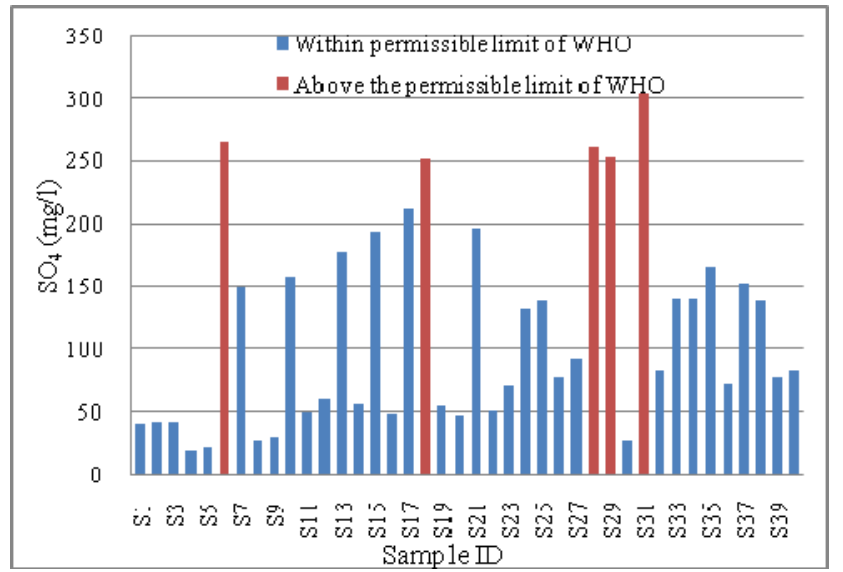

Fig. 3. Comparison of results of $\mathrm{SO}_{4}$ of all 40 samples
Results exhibit that the Sulfate $\left(\mathrm{SO}_{4}\right)$ concentration of 35 samples is within the maximum permissible limit specified by WHO. The sulfate concentration of $12.5 \%$ of the samples is above the permissible limit while the sulfate concentration of 10 samples was lower than the desirable limit of $50 \mathrm{mg} / \mathrm{l}$. The range $\mathrm{SO}_{4}$ of the samples was $20-302 \mathrm{mg} / \mathrm{l}$ and the average value was $115 \mathrm{mg} / \mathrm{l}$.

\section{Magnesium $(\mathrm{Mg})$}

$\mathrm{Mg}$ is one of the important minerals of water and is very essential for human health. The content of $\mathrm{Mg}$ in water is used to determine the quality of water for various purposes [5]. WHO has specified $150 \mathrm{mg} / \mathrm{l}$ of $\mathrm{Mg}$ for drinking water. $\mathrm{Mg}$ concentrations of all samples are within the maximum permissible limit. The magnesium content varied from 10 to $121 \mathrm{mg} / \mathrm{l}$ and the average value was $50.65 \mathrm{mg} / 1$.

\section{J. Calcium (Ca)}

Calcium is one of the most significant minerals of water which is indispensable for bones, teeth and cell physiology. Excess calcium consumption is very detrimental for human health [5]. WHO has not set any guide line value of $\mathrm{Ca}$ for drinking water. The range of $\mathrm{Ca}$ of all samples was $16-160 \mathrm{mg} / \mathrm{l}$ and the average value was $71.5 \mathrm{mg} / \mathrm{l}$.

\section{K. Hardness}

Water hardness is a very important parameter determining its potential use. Various minerals are dissolved in water impacting its hardness. Water hardness is often calculated as calcium carbonate concentration. It should be $500 \mathrm{mg} / \mathrm{l}$ in drinking water according to WHO. Drinking water has been classified on the basis of hardness as follows: Soft :between 0 and $75 \mathrm{mg} / 1$, moderately hard: between 75 and $150 \mathrm{mg} / 1$, hard: between 150 and $300 \mathrm{mg} / \mathrm{l}$ and very hard: greater than $300 \mathrm{mg} / \mathrm{l}$ [21]. The results of degree of hardness are shown in Figure 4.

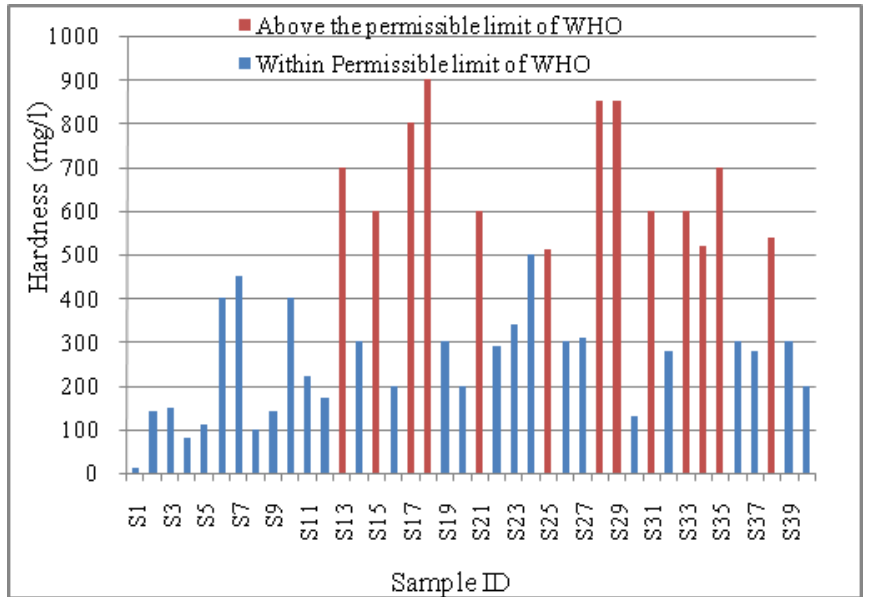

Fig. 4. Comparison of results of hardness of all 40 samples

Results indicate that the hardness of 27 samples is within the permissible limit, while $32.5 \%$ of the samples have hardness above the permissible WHO limit. The range of hardness of all 40 tested samples was $11-900 \mathrm{mg} / \mathrm{l}$ and the 
average value was $384.27 \mathrm{mg} / \mathrm{l}$. Only one groundwater sample was soft according to the above criteria. While 6 samples were moderately hard, 14 samples belonged to hard and the remaining 19 samples comprised very hard water. The analytical result shows that $82.5 \%$ of ground water samples of the study area fall in the category of hard to very hard water. Elevated level of water hardness creates heart and kidney problems [23].

\section{Sodium $(\mathrm{Na})$}

Sodium is one of the most common water metallic elements. Proper quantity of $\mathrm{Na}$ is very essential for the human body. Elevated $\mathrm{Na}$ level imparts its flavor to water and can be harmful for human health [24]. Its concentration should be $200 \mathrm{mg} / \mathrm{l}$ in drinking water according to WHO. The results of $\mathrm{Na}$ concentration are shown in Figure 5.

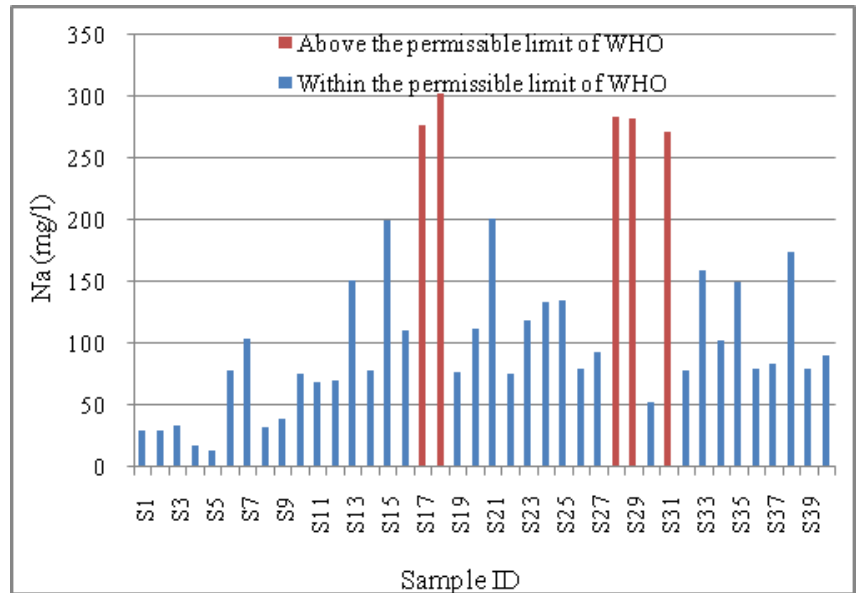

Fig. 5. Comparison of results of $\mathrm{Na}$ of all samples

Results indicate that the sodium concentration of 35 samples was found within the permissible limit given by WHO The remaining $12.5 \%$ of the samples possessed higher $\mathrm{Na}$ concentration. The range of $\mathrm{Na}$ concentration of all samples was $14-301 \mathrm{mg} / \mathrm{l}$ and the average value was $115.32 \mathrm{mg} / \mathrm{l}$.

\section{Potassium (K)}

Potassium is an alkali element. It is very essential for all living organisms, it is particularly found in cell tissues and helps in hydration [25]. WHO has not specified a permissible value of $\mathrm{K}$. However European Commission set $12 \mathrm{mg} / \mathrm{l}$ in water for drinking purpose. The results of $\mathrm{K}$ of all samples are shown in Figure 6. Results indicate that K concentrations of 39 samples are within the permissible limit given by EC and only 1 sample is beyond it. The range of $\mathrm{K}$ of all samples was 1$13 \mathrm{mg} / \mathrm{l}$ and the average value was as $4.61 \mathrm{mg} / \mathrm{l}$.

\section{N. Alkalinity}

Alkalinity is the presence of different components in water which make it alkaline. Alkalinity elevated level may create various health problems. No guide line value of alkalinity has been given by WHO. The range of alkalinity of the samples was $1.2-13.6 \mathrm{~m} . \mathrm{mol} / 1$ and the average value was calculated as $5.96 \mathrm{~m} \cdot \mathrm{mol} / 1$.

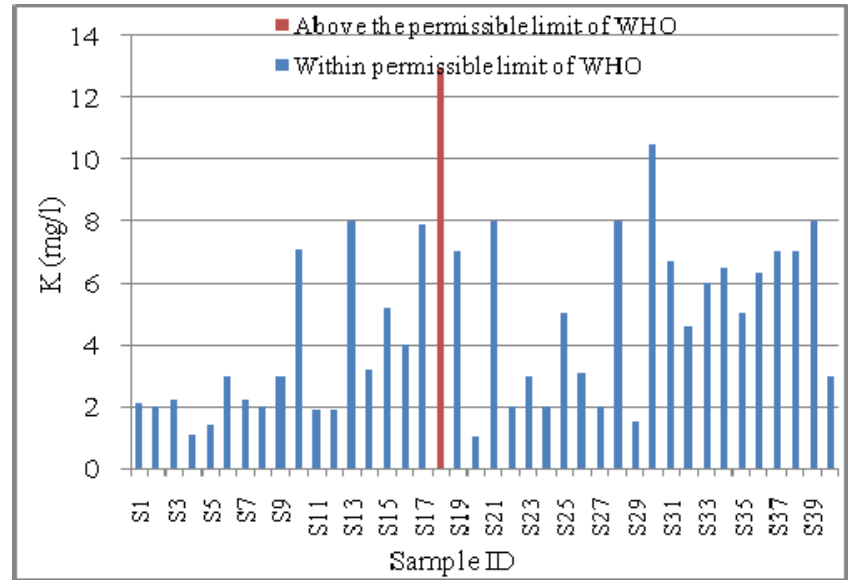

Fig. 6. Comparison of results of potassium of all samples

\section{O. Nitrate $\left(\mathrm{NO}_{3}\right)$}

Nitrate is an inorganic and water soluble compound derived from nitrogen and essential for plant life. The natural source of nitrate in groundwater is the atmosphere through the nitrogen cycle. Anthropogenic sources are leaching from industrial effluent, agricultural chemicals and sewage [26]. The consumption of groundwater having elevated level of nitrate may cause diabetes, thyroid disease, gastric cancer and methemoglobinemia [27]. WHO set the maximum permissible limit of nitrate as $10 \mathrm{mg} / 1$ in drinking water. The results show that nitrate levels of all samples are within this limit. The range of nitrate of the samples was $0.25-2.7 \mathrm{mg} / \mathrm{l}$ and the average value was $1.27 \mathrm{mg} / 1$.

\section{P. Microbiological Contamination}

The microbial contamination of groundwater is a severe cause of health concern. Dysentery, diarrhea, cholera, typhoid and polio are diseases which can be transmitted through contaminated water. The main sources of microbial contamination of water are human or animal feces and agricultural activity [27, 28]. Presence-absence test kit was used to evaluate the ground water samples for microbiological contamination. The results indicate that $75 \%$ of samples were free from microbiological contamination while $25 \%$ of samples showed positive results.

\section{CONCLUSIONS}

Results of this study revealed that $82.5 \%$ of groundwater samples of the study area belong to the category of hard to very hard water and the most $(82.5 \%)$ of the samples are alkaline in nature. Color, $\mathrm{pH}$, magnesium, alkalinity and nitrate of all the samples are found within the permissible limits of WHO. The analytical results revealed that the percentage of samples beyond permissible limits, regarding the tested parameters were taste $(15 \%)$, TDS $(42.5 \%), \mathrm{Cl}(20 \%)$, sulfate $(12.5 \%), \mathrm{Na}$ $(12.5 \%)$ and hardness $(32.5 \%)$. The microbiological contamination of $25 \%$ of the samples was found positive. 
Groundwater with parameters beyond permissible limits should not be used for drinking purpose.

\section{REFERENCES}

[1] H. Annapoorna, M. R. Janardhana, "Assessment of groundwater quality for drinking purpose in rural areas surrounding a defunct copper mine", Aquatic Procedia, Vol. 4, pp. 685-692, 2015

[2] K. M Anwar, V. Aggarwal, "Analysis of Groundwater Quality of Aligarh City, (India): Using Water Quality Index", Current World Environment, Vol. 9, No. 3, pp. 851-857, 2014

[3] R. B. Jackson, S. R. Carpenter, C.N. Dahm, D. M. McKnight, R. J. Naiman, S. L. Postel, S. W. Running, "Water in a changing world", Ecological applications, Vol. 11, No. 4, pp. 1027-1045, 2001

[4] N. Bhatti, S. R. Samo, M. A. Keerio, A. Q. Jakhrani, N. Z. Shar, "Assessment of Ground Water Quality of Taluka Kazi Ahmed District Shaheed Benzirabad", Engineering Science And Technology International Research Journal, Vol. 1, No. 2, pp. 64-74, 2017

[5] M. Mohsin, S. Safdar, F. Asghar, F Jamal, "Assessment of drinking water quality and its impact on residents health in Bahawalpur city", International Journal of Humanities and Social Science, Vol. 3, No. 15, pp. 114-28, 2013

[6] A. Azizullah, M. N. K. Khattak, P. Richter, D. P. Hader, "Water pollution in Pakistan and its impact on public health-a review", Environment International, Vol. 37, No. 2, pp. 479-497, 2011

[7] A. S. Qureshi, P. G. McCornick, A. Sarwar, B. R. Sharma, "Challenges and prospects of sustainable groundwater management in the Indus Basin, Pakistan”, Water Resources Management, Vol. 24, No. 8, pp. $1551-1569,2010$

[8] M. Y. Khuhawar, S. A. Majidano, "An Investigation of Quality of Groundwater of Taluka Nawabshah", Pakistan Journal of Chemistry, Vol. 1, No. 1, pp. 65-71, 2011

[9] A. S. Qureshi, P. G. McCornick, M. Qadir, Z. Aslam, "Managing salinity and waterlogging in the Indus Basin of Pakistan", Agricultural Water Management, Vol. 95, No. 1, pp. 1-10, 2008

[10] A. S. Qureshi, M. A. Gill, A. Sarwar, "Sustainable groundwater management in Pakistan: challenges and opportunities", Irrigation and Drainage, Vol. 59, No. 2, pp. 107-116, 2010

[11] M. A. Malik, M. Azam, A. Saboor, Water Quality Status of Upper KPK and Northern Areas of Pakistan, Pakistan Council of Research in Water Resources (PCRWR), Water Resources Research Centre, 2010

[12] R. Ullah, R. N. Malik, A. Qadir, "Assessment of groundwater contamination in an industrial city, Sialkot, Pakistan", African Journal of Environmental Science and Technology, Vol. 3, No. 12, pp. 429-446, 2009

[13] A. Q. Jakhrani, S. R. Samo, I. Nizamani, "Impact of wastewater effluents on physico-chemical properties of groundwater", Sindh University Research Journal-SURJ (Science Series), Vol. 41, No. 1, pp. 75-82, 2009

[14] W. M. Daudpota, N. U. N. Memon, T. F. Miano, "Determination Of Ground Water Quality For Agriculture And Drinking Purpose In Sindh, Pakistan. (a case study)", Science International, Vol. 28, No. 1, pp. 701704, 2016

[15] M. A. A. Beg, Status Of Safe Drinking Water in Sindh, Sindh Ombudsman's Secretariat, Shahrah-e-kamal Ataturk, 2002

[16] M. Memon, M. S. Soomro, M. S. Akhtar, K. S. Memon, "Drinking water quality assessment in Southern Sindh (Pakistan)", Environmental Monitoring and Assessment, Vol. 177, No. 1, pp. 39-50, 2011

[17] Pakistan Bureau of Statistics, Pakistan Social and Living Standards Measurements Survey (2014-15), Statistics Division Islamabad Pakistan, 2016

[18] J. Bartram, R. Ballance, Water quality monitoring: a practical guide to the design and implementation of freshwater quality studies and monitoring programmes, CRC Press, 1996

[19] World Health Organization, Guidelines for Drinking Water Quality, Surveillance and Control of Community Supplies, Vol. 3, WHO, 1997
[20] A. D. Eaton, L. S. Cleceri, E. W. Rice, A. E.Greenberg, (eds), Standard methods for the examination of water and wastewater, American Public Health Association, 2005

[21] S. S. Prasanth, N. S. Magesh, K. V. Jitheshlal, N.Chandrasekar, K. Gangadhar, "Evaluation of groundwater quality and its suitability for drinking and agricultural use in the coastal stretch of Alappuzha District, Kerala, India”, Applied Water Science, Vol. 2, No. 3, pp. 165-175, 2012

[22] United States Enviromental Protection Agency, Drinking Water Advisory: Consumer Acceptability Advice and Health Effects Analysis on Sulfate, 2003

[23] S. M. Sadat-Noori, K. Ebrahimi, A. M. Liaghat, "Groundwater quality assessment using the Water Quality Index and GIS in Saveh Nobaran aquifer, Iran”, Environmental Earth Sciences, Vol. 71, No. 9, pp. 38273843,2014

[24] A. J. Kandhro, A. M. Rind, A. A. Mastoi, K. F. Almani, S. Meghwar, M. A. Laghari, M. S. Rajpout, "Physico-chemical assessment of surface and ground water for drinking purpose in Nawabshah city, Sindh, Pakistan", American Journal of Environmental Protection,Vol. 4, No. 1, pp. 62-69, 2015

[25] W. Orzepkowski, K. Pulikowski, "Magnesium, calcium, potassium and sodium content in groundwater and surface water in arable lands in the commune gmina of Katy Wroclawskie", Journal of Elementology, Vol. 13, No. 4, pp. 605-614, 2008

[26] H. T. Basavarajappa, M. C. Manjunatha, "Groundwater quality analysis in Precambrian rocks of Chitradurga district, Karnataka, India using Geo-informatics technique", Aquatic Procedia, Vol. 4, pp. 1354-1365, 2015

[27] J. P. S. Cabral, "Water Microbiology. Bacterial Pathogens and Water", International Journal of Environmental Research and Public Health, Vol. 7, No. 10 , pp. 3657-3703, 2010

[28] P. K. Pandey, P. H. Kass, M. L. Soupir, S. Biswas, V. P. Singh, "Contamination of water resources by pathogenic bacteria", AMB Express, Vol. 4, No. 1, p. 51, 2014 